Katarzyna Karpińska-Szaj

Uniwersytet im. Adama Mickiewicza w Poznaniu

kataszaj@amu.edu.pl

Bernadeta Wojciechowska

Uniwersytet im. Adama Mickiewicza w Poznaniuj

bewoj@amu.edu.pl

\title{
PRZEFORMUŁOWANIE W PRZYSWAJANIU I UCZENIU SIĘ JĘZYKÓW: SPECYFIKA I FUNKCJE ODTWARZANIA OPOWIADANIA
}

\section{Reformulation in language acquisition and learning: the nature and functions of story retelling}

This article is about a task which required learners to reformulate a story which they had listened to in writing. In the context of foreign language learning, the original text provides a discourse model, whereas the way it is rephrased reflects students' skill to use the new information in their own words. Retelling can also be treated as language practice focused on learning and practising new vocabulary and sentence structures. The research concentrated on fragments of text that were an extension of the original text that was retold by an elementary group of students of French philology (A2 level according to The Common European Framework of Reference for Languages, 2003) in Polish and French (the foreign language). Comparison of speech produced in the two languages made it possible to consider the nature and function of the learners' discourse competence which, depending on the students' personal goals and communicative experience, differed in the two cases. The data collected can serve as a starting point for planning further steps to develop students' metadiscoursal awareness with the use of the retelling of a story as a learning strategy. 
Keywords: teaching/learning French as a foreign language, reformulation, retelling story, discourse competence, learning strategies

Słowa kluczowe: nauczanie/uczenie się języka francuskiego jako obcego, przeformułowanie, odtwarzanie opowiadania, kompetencja dyskursywna, strategie uczenia się

\section{Uwagi wstępne: wykorzystanie badań nad akwizycją języka w glottodydaktyce}

Badania nad przyswajaniem języka ojczystego mogą być wykorzystane w glottodydaktyce i stanowić źródło inspiracji do modelowania procesu uczenia się/ nauczania, choć oczywistym jest, że specyfika przyswajania języka ojczystego i uczenia się języka obcego jest inna. Cechą interdyscyplinarności obu obszarów badawczych nie jest przełożenie zaobserwowanych etapów akwizycji na poszczególne stadia kształtowania językowych kompetencji komunikacyjnych w języku obcym oraz ich ewentualne kontrastowanie (uchwycenie różnic). Ten etap wzorowania się na badaniach nad akwizycją języka ojczystego był widoczny w starszych metodach nauczania: metoda audio-oralna i metodologia SGAV są najbardziej znanymi przykładami tego podejścia.

Wraz z rozwojem badań nad dyskursem i wzrostem znaczenia interakcji w kształtowaniu sprawności językowych zarówno w funkcji reprezentatywnej jak i komunikacyjnej, zmieniała się optyka powiązań między tymi dziedzinami badań: od tendencji aplikacyjnej (stosowania wniosków z badań akwizycyjnych w glottodydaktyce) zmierza się obecnie do autonomii dyscyplinarnej zasadzającej się głównie na wyróżnieniu celów badawczych specyficznych dla zaobserwowanego problemu. Obranie dyskursu jako paradygmatu w naukach językoznawczych spowodowało przesunięcie badań z opisu procesów decydujących o przyswajaniu struktur językowych do specyfiki kształtowania poszczególnych rodzajów kompetencji decydujących o jakości rozumienia i produkcji wypowiedzi oraz znaczenia interakcji w rozwijaniu sprawności językowych.

W tej stosunkowo nowej optyce, badania akwizycyjne dotyczące rozwoju kompetencji dyskursywnej zmierzają głównie do ustalenia poszczególnych stadiów rozwojowych, pomijając opis i analizę procesów, które je warunkują (zob. np. Bartning i Kirchmeyer (2003) dla kompetencji tekstowej w języku francuskim jako obcym uczniów szwedzkojęzycznych). W konsekwencji, z badań tych trudno jest pozyskać dane umożliwiające konceptualizację roli i 
efektów interwencji dydaktycznej (Bronckart, 1996: 57). Badania nad akwizycją języka dotyczą w większości wyizolowanych jednostek/struktur językowych lub umiejętności. Tymczasem każde uczenie się języków, które to wszak jest przedmiotem badań glottodydaktycznych, dąży do coraz dalej posuniętej integracji i uogólnienia - wyabstrahowania z kontekstu nabycia oraz transponowania na inne, nowe konteksty (zob. krytyczny przegląd tych badań w Canut i Vertalier, 2010). Celem dydaktycznym jest obserwacja indywidualnej dynamiki uczenia się - nie można zatem ograniczyć badań do wyróżniania stadiów i ich porównywania, by w efekcie uśredniać dane w celu wyróżnienia tzw. normy na danym etapie nauczania. W perspektywie nauczania/uczenia się istotne jest bowiem wyróżnienie indywidualnych faz nabywania form językowych, testowanych przez ucznia i ich odniesienie do elementów rzeczywiście poznanych (już opanowanych). Takiemu podejściu towarzyszy równolegle dążenie do uchwycenia pewnych bardziej ogólnych prawideł i zależności w nauczaniu/uczeniu się języków obcych.

Wykorzystanie badań nad akwizycją języka w glottodydaktyce polega więc na inspiracji użytą metodologią pozyskiwania danych i poszerzeniu ich o aspekty cenne z punku widzenia nauczania/uczenia się języka/języków. Chodzi o prześledzenie indywidualnych ścieżek rozwoju ucznia, wyjaśnienie ich specyfiki i zmienności, ustalenie prawideł i tendencji dających się uogólnići mogących stanowić podstawę dydaktycznego kształtowania. Tym samym w niniejszym artykule będziemy zmierzać do odpowiedzi na pytania, jak na danym etapie uczący się wykorzystuje dane wejściowe (input) użyte w sytuacji zadaniowej, gdy tekst wyjściowy jest gatunkiem podobnie realizowanym w obu kulturach, oraz jaką rolę $w$ tym procesie odgrywa kompetencja dyskursywna.

\section{Przeformułowanie w przyswajaniu i uczeniu się języka}

Wykorzystane w badaniu zadanie powtórzenia z pamięci usłyszanego opowiadania definiowane jest jako "proces odtworzenia wypowiedzi, w której elementy zachowane z wypowiedzi źródłowej łączą się z elementami zmodyfikowanymi w stosunku do tej wypowiedzi. Modyfikacja może dotyczyć poziomu leksykalnego, składniowego lub semantycznego" (Martinot, 2012 [1994]: 65). To właśnie za pomocą przeformułowania dziecko buduje swoją kompetencję językową w języku ojczystym, a w trakcie nauki języka obcego uczeń może posłużyć się tym narzędziem jako strategią uczenia się. Oznacza to, że mniej lub bardziej wierne wzorowanie się na cudzych wypowiedziach, które jest działaniem naturalnym w procesie akwizycji, może też być wykorzystane w sposób systematyczny i zorganizowany $w$ procesie uczenia się. 


\subsection{Hipoteza akwizycyjna - znaczenie przeformułowania}

W badaniach nad przyswajaniem języka ojczystego, przeformułowanie zostało wykorzystane jako narzędzie badawcze w celu zaobserwowania progresji posługiwania się konstrukcjami złożonymi w zależności od wieku, stymulacji językowej oraz cech/zaburzeń rozwojowych dzieci (zob. np. Préneron i Martinot, 2013). Założono w nich, zgodnie z przyjętym paradygmatem badawczym, tj. hipotezą akwizycyjną wywodzącą się z badań nad przekształcaniem wypowiedzi przez dzieci w fazie wczesnego przyswajania języka ojczystego, że w przeformułowywanych wypowiedziach można zaobserwować kolejne stadia nabywania umiejętności tworzenia wypowiedzi z użyciem językowych konstrukcji złożonych. Zgodnie z tą hipotezą dziecko wykształca językowe kompetencje komunikacyjne na podstawnie danych językowych z otoczenia, stopniowo zwiększając repertuar środków językowych, w skład których wchodzą struktury złożone wyrażone w przeformułowanych wypowiedziach za pomocą różnego rodzaju parafraz.

Interesujące jest skorelowanie tych umiejętności z rozwijaniem kompetencji dyskursywnej, tj. zaobserwowanie np., w jaki sposób dzieci dochodzą do pewnych etapów narracji używając konkretnych środków językowych. Odtworzenie tekstu źródłowego pozwala przyjrzeć się powstałej wypowiedzi pod kątem komunikacyjnej i reprezentatywnej funkcji języka. Na funkcję komunikacyjną podczas przeformułowania składają się przywołane już środki językowe (zasoby leksykalne, poprawność gramatyczna i semantyczna, złożoność wypowiedzi) oraz sposoby kontrolowania wypowiedzi (przekazanie treści zrozumiałych dla odbiorcy). Funkcja reprezentatywna w przeformułowaniach dzieci przejawia się głównie w sposobie prowadzenia narracji. Na postawie zebranych danych można zaobserwować następującą progresję: wyjście poza wyliczenie obiektów/postaci/wydarzeń, poprzez opis stanów emocjonalnych i działań bohaterów do interpretacji, wyjaśniania sytuacji. Jakość narracji, choć zależy od potencjału poznawczego dziecka na danym etapie rozwoju (zasobów pamięci, kierowania uwagą), pozostaje jednak w ścisłym powiązaniu z jego repertuarem językowym oraz doświadczeniem dyskursywnym (por. np. badanie przeprowadzone w celu diagnozy kompetencji językowych dzieci z niedoborami języka polskiego w Karpińska-Szaj, 2015).

Rzecz jasna w przypadku języka obcego nie można mówić o identycznych procesach, gdyż w trakcie jego nauki przez osoby o ukształtowanych już językowych kompetencjach komunikacyjnych w języku ojczystym, nabywanie środków językowych nie wyprzedza nabywania umiejętności tworzenia dyskursu (zob. Py, 1996; Bronckart, 2008). Na przykład na początkowych etapach dorośli uczący się języka obcego skupiają się raczej na konfiguracji leksykalnej, 
pragmatycznej i dyskursywnej wypowiedzi niż na jej gramatycznym uporządkowaniu (Véronique, 2005: 10). Taka postawa uczących się jest związana z doświadczeniem dyskursywnym w języku ojczystym. Polega ono na znajomości gatunków i norm społecznego użycia języka w sytuacjach podobnych, w tym również na opanowaniu przynajmniej podstawowych mechanizmów tekstowych (zasady spójności, organizowania i hierarchizowania informacji w ramach większych jednostek tekstowych). W nauce języka obcego doświadczenie dyskursywne i tekstowe może znacznie przewyższać kompetencję językową. W kontekście dydaktycznym tendencja ta może, przy odpowiednim prowadzeniu, stanowić dużą pomoc w planowaniu i organizowaniu wypowiedzi, a także w obserwowaniu wypowiedzi cudzych w celu pozyskania brakujących środków językowych pozwalających na pełniejszą realizacje celów komunikacyjnych. Chodzi o to, by uczeń w kontakcie z materiałem stymulującym, jakim jest tekst, nie skupiał się tylko na zrozumieniu znaczenia, ale korzystał z tej okazji do tworzenia i weryfikowania hipotez dotyczących funkcjonowania języka w dyskursie. Jest to gwarantem połączenia reguły gramatycznej z normą dyskursywną, co z kolei warunkuje jej pełne przyswojenie i swobodne użycie w komunikacji.

\subsection{Przeformułowanie jako strategia uczenia się języka obcego}

W kontekście uczenia się/nauczania języka obcego powiązanie kompetencji językowej z kompetencją dyskursywną spełnia też funkcję strategii uczenia $\operatorname{się}^{1}$. Jednak aby przeformułowanie mogło stać się strategią uczenia się integrującą oba rodzaje kompetencji, proponowany tekst wyjściowy powinien posiadać autentyczne cechy gatunkowe, a wybrana reguła językowa powinna być poddana świadomemu przetwarzaniu w powiązaniu z bardziej ogólnymi schematami dyskursywnymi. Tekst wyjściowy stanowi bowiem w kontekście uczenia się języka obcego model dyskursywny oraz źródło danych językowych, a sposób jego odtwarzania odzwierciedla umiejętność wykorzystania dostarczonych danych w wypowiedzi własnej.

Rozwój kompetencji dyskursywnych polega między innymi na wzbogacaniu środków językowych oraz ich integrowaniu z normą społecznego ich użycia. Reguła językowa dotyczy poziomu wyrazu i zdania, a więc sposobu łączenia elementów niższego rzędu oraz łączliwości międzyzdaniowej na poziomie

\footnotetext{
${ }^{1}$ Należy tutaj zaznaczyć, że wyróżnienie tych dwóch rodzajów kompetencji zostało dokonane na potrzeby analizy, w rzeczywistości bowiem występują one $w$ formie zintegrowanej i stanowią wtedy pełną kompetencję komunikacyjną. Zgodnie z tą specyfiką komunikacji językowej, nauka języka obcego polega na rozwijaniu i integrowaniu poszczególnych składowych kompetencji komunikacyjnej.
} 
tekstu. Natomiast norma dyskursywna wiąże się ze sposobem prezentowania treści, jej progresją, uwzględnianiem szeroko rozumianego kontekstu (typu dyskursu, sytuacji komunikacyjnej, gatunku, intencji mówiących etc.). Norma dyskursywna jest zmienna, wielowymiarowa, ta sama funkcja może być realizowana przez wiele struktur w danej sytuacji komunikacyjnej, która z kolei jest zdefiniowana przez cel komunikacyjny, status interlokutorów, podzielaną wiedzę, poglądy, nastawienia, intencje. Parametry dyskursywne wypowiedzi mogą zatem kierować wysiłkami ucznia w nabywaniu sprawności gramatycznej, a ich uchwycenie może rozwijać wrażliwość obserwacyjną i realizacyjną uczących się, umożliwiając jednocześnie bardziej świadomy wybór kolejnych celów uczenia się i kompletowanie niezbędnych po temu wzorców i zasobów językowych².

Przeformułowanie jest zatem narzędziem, które integruje językowe kompetencje komunikacyjne na ich poszczególnych poziomach w trakcie wykonywania zadania oraz rozwija sprawność uczenia, gdyż:

- łączy procesy rozumienia i zapamiętywania;

- mobilizuje wykorzystanie i rozwijanie wiedzy o interdyskursie, wariantywności gatunkowej w zależności od parametrów sytuacji;

- wymusza uwzględnienie typów tekstu i sposobów ich komponowania w ramach gatunku;

- warunkuje dobór środków językowych, zastosowania reguł łączliwości wewnątrz i zewnątrzzdaniowej.

Można przyjąć, że osoba dorosła ucząca się nowego języka obcego posiada już świadomość dyskursywną w języku ojczystym i ewentualnie w innych znanych już językach, jest więc wysoce prawdopodobne, że świadomość ta nie pozostaje bez wpływu na przetwarzanie tekstu w proponowanych zadaniach dydaktycznych zasadzających się na przeformułowaniu. W opisanym poniżej zadaniu dydaktycznym postawiłyśmy sobie za cel prześledzenie sposobów przeformułowania językowych danych wejściowych użytych w konkretnym opowiadaniu (gatunku realizowanym podobnie w obu kulturach) oraz roli, jaką w tym zadaniu spełnia kompetencja dyskursywna.

\section{Badanie własne}

W badaniu posłużyłyśmy się opowiadaniem przygotowanym na potrzeby realizacji międzynarodowego projektu badawczego "Złożoność językowa w wieku

\footnotetext{
${ }^{2}$ Taką współzależność kompetencji językowej i kompetencji dyskursywnej wykazano w konkretnej sytuacji uczenia się/nauczania podsystemu morfo-syntaktycznego przez początkujących studentów filologii romańskiej w badaniu opisanym przez autorki w 2015 roku (Karpińska-Szaj i Wojciechowska, 2015).
} 
6 do 14 lat. Przyswajanie, produkcja wypowiedzi, przetwarzanie"³, którego celem jest zebranie korpusu językowego dzieci w różnych przedziałach wiekowych i określenie na jego podstawie potencjału językowego umożliwiającego produkcję wypowiedzi ustnej na podstawie odsłuchanego tekstu narracyjnego. Do opisywanego tu doświadczenia wykorzystałyśmy tekst wyjściowy w języku polskim i francuskim (zob. załącznik). Opowiadanie o przygodach pary bohaterów zawiera wiele struktur złożonych, które w założeniach projektu mają posłużyć do wyróżnienia poszczególnych typów parafraz oraz oszacowania złożoności przetworzonych struktur językowych, a w naszym zadaniu umożliwić prześledzenie i porównanie użytych przeformułowań w obu językach.

W badaniu wzięło udział ośmiu studentów filologii romańskiej, reprezentujących poziom A2 wg ESOKJ. Zaproponowano dwie sytuacje dydaktyczno-badawcze:

(1) w języku francuskim: najpierw odczytanie przez prowadzące badanie opowiadania, potem jego pisemne odtworzenie przez badanych studentów;

(2) w języku polskim: po dwóch tygodniach odczytanie tego samego opowiadania i jego pisemne odtworzenie przez badanych.

Analizie jakościowej poddano całe teksty odtworzone przez studentów w obu językach. Studenci zostali poproszeni o wypowiedź na temat użytych strategii odtworzenia tekstu w obu sytuacjach w trakcie wywiadu przeprowadzonego po wykonaniu drugiego zadania.

\subsection{Dyskursywna specyfika przeformułowania opowiadania w języku polskim}

Analiza odtworzonych przez studentów opowiadań pozwala stwierdzić wysoki stopień poprawności i wierności wykonanego przeformułowania w odniesieniu do tekstu wyjściowego. Zwracają uwagę liczne sformułowania powtórzone dokładnie lub niemal tak samo dokładnie jak w tekście wyjściowym. Obok przeformułowanych fragmentów znalazło się też sporo elementów dodanych, które w znaczący sposób wzmacniają kohezję tekstową (wewnętrzną) i koherencję (spójność zewnętrzną) za pomocą złożonych struktur leksykalno-gramatycznych. W poniższym fragmencie odtworzonego opowiadania w języku polskim przez studentkę AK, wyróżniono elementy dodane w stosunku do tekstu wyjściowego:

\footnotetext{
${ }^{3}$ « La complexité linguistique de 6 à 14 ans. Acquisition, production, traitement » jest zadaniem badawczym grupy Sens Texte Informatique Histoire koordynowanym przez prof. Claire Martinot z Uniwersytetu Paris Sorbonne. Ze strony polskiej partnerami w projekcie są prof. Urszula Paprocka-Piotrowska (Katolicki Uniwersytet Lubelski) oraz prof. Katarzyna Karpińska-Szaj i dr Bernadeta Wojciechowska (Uniwersytet im. Adama Mickiewicza w Poznaniu).
} 
„Tamtego ranka pani przybyła na podwórko później niż zazwyczaj. Kiedy w końcu nadeszła trzymała za rękę małą dziewczynkę. (...) Chłopiec bardzo się ucieszył na myśl, że zyska nową koleżankę. Myśląc o nowej kompance po powrocie do domu przygotował dla niej złoto-czerwone pudełko. Kiedy pani kazała wyjmować swoje rzeczy na początku zajęć, Julka zawsze kładła złoto-czerwony prezent na ławce pomiędzy nią a Tomkiem. Pewnego dnia Julka poprosiła Tomka, by otworzył pudełko. Chłopiec posłusznie wykonał polecenie i zobaczył małą karteczkę, na której było napisane, by spotkał się z Julką tego dnia wieczorem, o godzinie ósmej przy wejściu do lasu. Tomek przestraszył się trochę, ponieważ nie wolno mu było wychodzić tak późno w nocy. Mimo to po raz kolejny posłuchał swojej koleżanki. Julka oświadczyła swojemu koledze, że dziś wydawana jest uczta na jego cześć. Ponadto może on poprosić o cokolwiek (...)." [AK]

Obok wzmocnienia wewnętrznej i zewnętrznej spójności tekstu dodane elementy spełniają też inne funkcje dyskursywne. Przede wszystkim wzbogacają one opowiadanie o elementy, które można zakwalifikować jako należące do drugiego planu narracji, tj. nie tyle do wydarzeń, ile do towarzyszących ich uczuciom i ocenom. Ponadto wpisują się w relację, wirtualną czy wyobrażeniową, ze słuchaczem próbując wpływać na jego odbiór wydarzeń. Taką funkcję spełnia np. zdanie okolicznikowe zawierające wyrażenie przysłówkowe "Kiedy w końcu nadeszła", które wyraża emocjonalny stosunek osoby opowiadającej do odtwarzanych treści, a także zawiera implicytną informację o niecierpliwym oczekiwaniu uczniów na nauczycielkę. Nie było o tym mowy w oryginalnej wersji opowiadania, trzeba jednak przyznać, że zabieg ten wyraźnie podnosi atrakcyjność historyjki. Podobną funkcję retoryczną pełnią spójniki "mimo to", który wyraża napięcie między strachem a ciekawością chłopca oraz "ponadto", które nawet bardziej niż w tekście wyjściowym wskazuje na rozmiary niespodzianki.

Na kilka słów komentarza zasługują też zabiegi, które spełniają podwójną rolę: $z$ jednej strony wprowadzają interpretację - w tym przypadku słów dziewczynki jako polecenia "Chłopiec posłusznie wykonał polecenie" oraz kwalifikację i zarazem ocenę działań chłopca, jako wynikających z posłuszeństwa "posłusznie wykonał" i kilka zdań dalej "Mimo to po raz kolejny posłuchał swojej koleżanki"; z drugiej strony elementy te spinają niejako opowiadanie łącząc dwa niebezpośrednio następujące po sobie wydarzenia za pomocą wyrażenia przysłówkowego "po raz kolejny", dodatkowo wpisując ją w sugerowaną logikę działań chłopca. Podobnie podwójną rolę odgrywa imiesłów w wyrażeniu "myśląc o nowej kompance", który nie tylko zapewnia progresję budując łączliwość międzyzdaniową za pomocą anafory "kompance", ale też dodaje drugi, równoległy plan narracji opisujący uczucia i myśli bohatera. Wielość funkcji dających się wyróżnić w tych kilku przykładach może być 
przedmiotem refleksji nauczyciela z uczniami o tym, jak bardzo różne plany opowiadania (językowy, tekstowy i dyskursywny) się przenikają i jak silnie są ze sobą zintegrowane w konkretnych działaniach komunikacyjnych.

Opisane wyżej zabiegi integrujące różne funkcje dyskursywne można uznać za bardzo częste w opowiadaniach odtwarzanych w języku ojczystym, jak choćby w następującym fragmencie odtworzonego tekstu studentki KK: "Tomek nie był chętny, żeby tam iść, ponieważ nie wolno było mu samemu wychodzić do lasu i to zwłaszcza wieczorem. Pomimo swoich obaw wyszedł on i spotkał się z Julią" [KK]. W wielu fragmentach dążenie do uspójnienia i doprecyzowania treści opowiadania odbywa się w oparciu o własną wiedzę o świecie zewnętrznym lub o świecie baśniowym, na przykład: "Julka czekała tam, złapała go za rękę, a drugą 3 razy zapukała" [MW] ${ }^{4}$, czy "Julka spytała go, jako że byli w miejscu magicznym, co chciałby umieć" [PT]. Dość liczne są też przykłady dodanych fragmentów wprowadzające elementy interpretacji oraz informacje dotyczące tzw. "drugiego planu": "Przedstawiła ją całej klasie. Powiedziała, że nazywa się Julka i usadziła ją w ławce obok Tomka dając mu do zrozumienia, iż ma być dla niej miły" oraz "Tomek tak polubił Julkę, że zrobił dla niej w domu okrągłe złoto-czerwone pudełko" [MW].

Ta krótka analiza dość jednoznacznie pokazuje, jak bardzo odtworzony tekst opiera się na znanych uczniom schematach gatunkowych i dyskursywnych. Wydaje się bowiem, że bez ich znajomości nie tylko wierne odtworzenie wydarzeń byłoby trudniejsze dla uczniów, ale przede wszystkim trudno byłoby wytłumaczyć zaobserwowaną wyraźną tendencję do uzupełniania tych wydarzeń o emocje mogące im towarzyszyć za pomocą modalizacji, kwalifikacji czy znaczników wypowiadania (fr. indices d'énonciation). Swobodny dostęp do zasobów językowych sprawił, że funkcje dyskursywne są realizowane za pomocą struktur złożonych (np. zdań podrzędnie złożonych, imiesłowów, nominalizacji, zdań wtrąconych), a przede wszystkim, że plan językowy, tekstowy i komunikacyjny, jak już sygnalizowałyśmy, są silnie zintegrowane.

\subsection{Dyskursywna specyfika przeformułowania opowiadania w języku francuskim}

Odtworzenie tak długiego opowiadania w języku francuskim na poziomie A2 stanowiło dużo większe wyzwanie dla studentów. W pracach studentów daje się zauważyć różnice w sposobie radzenia sobie z zadaniem zapamiętywania tekstu w celu jego odtworzenia. Mimo tej różnorodności można jednak sformułować, na podstawie analizy całego korpusu, kilka spostrzeżeń bardziej ogólnych.

\footnotetext{
${ }^{4}$ W tekście oryginalnym: „Bez słowa dziewczynka wzięła Tomka za rękę i trzy razy zastukała w pień wielkiego drzewa”.
} 
Po pierwsze, widać wyraźnie mniejszą dokładność w odtwarzaniu tekstu, choć $z$ naszego punktu widzenia nie to jest najistotniejsze. Dużo ciekawsze wydaje się zaobserwowanie, że opuszczone fragmenty dotyczą przede wszystkim treści tła wydarzeń wyrażonych w tekście wyjściowym za pomocą struktur złożonych, tak jakby uczniowie skupili się przede wszystkim na odtworzeniu głównych działań bohaterów pomijając działania pośrednie i/lub cząstkowe i niektóre ich okoliczności. Dodajmy, że zasadniczo brak tych elementów nie zakłócił progresji odtworzonego opowiadania rozumianego jako ciągu zdarzeń, niemniej wpłynął znacząco na obniżenie atrakcyjności narracji, jej walorów retorycznych i estetycznych.

Podobnie jak to miało miejsce w przypadku odtwarzania opowiadania w języku ojczystym, również w przypadku języka obcego można zaobserwować wysiłki studentów w celu zapewnienia kohezji tekstu, jak np. w wypowiedzi JK « Soudain ils étaient dans le jardin. Le roi de ce jardin pouvait faire quelque chose pour Tom » (pl. "Nagle byli w ogrodzie. Król tego ogrodu mógł zrobić coś dla Tomka"). Dokonuje się to jednakże za pomocą najprostszych środków językowych, zdań prostych lub co najwyżej współrzędnie złożonych. Związki między zdarzeniami są wyrażone często w sposób implicytny, zdarzają się jednak, choć rzadko, przykłady, w których uczeń sygnalizuje je w bardziej eksplicytny sposób tak jak w podanym niżej fragmencie za pomocą spójnika donc (pl. więc) łącząc na dodatek działanie z motywacją bohatera, np. " Il voulait donner quelque chose pour Julie donc à la maison il a fait une boîte » (pl. "Chciał dać coś Julie więc w domu zrobił dla niej pudełko") [PT].

Fragmenty dodane, które nas w tym badaniu szczególnie interesują, dotyczą zawsze tła wydarzeń i uczuć bohaterów. Jak już wspomniano, w przeciwieństwie do języka ojczystego, wyrażone są one za pomocą struktur prostych i co znamienne, wynikają z dużo swobodniejszej niż w przypadku języka ojczystego interpretacji opowiadania. Wydaje się, że dodane elementy tła, mające na celu wyjaśnianie uczuć i motywacji bohaterów są dużo bardziej zakotwiczone we własnym doświadczeniu uczniów niż w świecie przedstawionym w opowiadaniu. Uzupełnienia tego typu są częstsze w części opowiadania dotyczącej szkoły niż w części dotyczącej zaczarowanego ogrodu i króla. Sam fakt jednak, że uczniowie włączyli je do opowiadania może świadczyć o odwołaniu się, mniej lub bardziej świadomym, do doświadczenia dyskursywnego uczniów w języku ojczystym. Przykładem takiego działania jest wypowiedź MK odnosząca się do jednej z początkowych sekwencji tekstu wyjściowego5: « Ils

\footnotetext{
${ }^{5}$ W tekscie wyjściowym: « Arrivée en classe, la maîtresse a dit « Les enfants, je vous présente votre nouvelle camarade, elle s'appelle Julie. Tom, la place est libre à côté de toi, Julie sera ta voisine, sois bien gentil avec elle ! ".
} 
se aimaient et faisaient beucoupe* des choses ensemble " (pl. Lubili się $i$ robili dużo rzeczy razem) i odtworzenie tego fragmentu przez $A M$ « C'était une nouvelle copine dans la classe. Tom a pensé a elle. II a voulu jouer avec elle et fait reconnaissance* » ( $p l$. To była nowa koleżanka w klasie. Tomek pomyślał o niej. On chciał bawić się z nią i poznać ją).

Analizując odtworzone opowiadania nie można oprzeć się wrażeniu, że część zastosowanych przez studentów zabiegów ma charakter kompensacyjny. Jest tak prawdopodobnie również w przypadku słowa voisine pochodzącego z tekstu wyjściowego, gdzie możliwa wątpliwość co do użycia tego słowa w kontekście ławki szkolnej pociąga za sobą parafrazę wyjaśniającą: « Elle est la voisine de Tom juste dans la classe, elle s'asseis* à côté de Tom. Ils parlent beaucoup » (pl. Ona jest sąsiadką Tomka tylko w klasie, siedzi obok Tomka. Dużo ze sobą rozmawiają) [PT].

W przedstawionych powyżej przykładach z założenia nie analizowałyśmy błędów językowych, skupiając się na normie dyskursywnej, ich obecność wskazuje jednak, że część trudności w odtworzeniu opowiadania może wynikać z niepełnej automatyzacji reguł językowych w pisaniu, tym bardziej, że uczniowie zgodnie stwierdzali, że tekst wyjściowy był dla nich w pełni zrozumiały.

\subsection{Dane pozyskane z wywiadów}

W przedstawionej sytuacji badawczej, która jest jednocześnie sytuacją uczenia się, zaproponowany wywiad po wykonaniu zadania odtworzenia opowiadania w języku francuskim i polskim miał na celu wyłonienie i uświadomienie uczniowi jemu właściwego funkcjonowania komunikacyjnego w obu kontekstach. Zamierzeniem wywiadu było zatem, z jednej strony, pozyskanie danych empirycznych, wyjaśniających decyzje doboru środków językowych w odniesieniu do odtwarzanego typu tekstu i rodzaju dyskursu w obu językach, a z drugiej strony, zaproszenie do refleksji nad wykonanymi zadaniami i oszacowanie ich wartości w budowaniu świadomości językowej i dyskursywnej. Za zgodą studentów wywiady zostały nagrane, a nagrania poddane transkrypcji.

Z pozyskanych danych wynika, że studenci zdawali sobie sprawę z ograniczeń wynikających z braku zautomatyzowania konstrukcji językowych w języku francuskim, co nie miało większego wpływu na zapamiętanie treści, jednak znacznie ograniczyło ich odtworzenie w języku obcym. Przykładem jest wypowiedź JK:

„Z tym słuchaniem miałam taki problem, że w głowie przechodziło mi to na język polski i zapamiętywałam to po polsku i potem te słowa, które gdzieś się pojawiały i które zrozumiałam ze względu na kontekst, nie mogłam potem użyć ich z powrotem po francusku bo znałam je jakby tylko z tego kontekstu a nie w tłumaczeniu z polskiego na francuski". [JK] 
JK zwraca też uwagę na konieczność, w jej przypadku, werbalizowania treści w celu ich zapamiętywania. Ze względu na wysoki poziom kompetencji dyskursywnej przyswojonej w języku ojczystym, scenariusz opowiadania tworzył się („zapisywał”) w fazie rozumienia w języku polskim. JK miała wrażenie zrozumienia treści, jednak nie potrafiła ich w pełni wyrazić w języku francuskim. Na podobną trudność wskazuje też AK:

"Co się po kolei działo przychodzi pani znaczy nie przychodzi pani, spóźnia się, przychodzi nowa dziewczynka tutaj musi usiąść, to wszystko po kolei sobie w głowie układałam, jakby plan wydarzeń". [AK]

AK posłużyła się znanym jej schematem narracyjnym w celu zrozumienia, co wskazuje na wyższy poziom kompetencji tekstowej w stosunku do kompetencji językowej. Studenci zauważyli tę zależność kompetencji dyskursywnej i kompetencji językowej porównując oba zadania. W większości przypadków potrafili wskazać przyczynę większego panowania nad posiadanym repertuarem językowym w odniesieniu do fragmentów niezdeterminowanych treścią w odsłuchanych tekstach. Świadczy o tym stosunkowo duża złożoność językowa odnotowana we fragmentach dodanych, wynikających z interpretacji treści, mających na celu zapewnienie spójności odtwarzanego tekstu, a także wyjaśnianie zachowań bohaterów. Przykładem jest wypowiedź JK:

„Znacznie mniejszy problem miałam z szukaniem słów jak pisałam sama z siebie, to było tak jakbym znała swoje granice, możliwości swojego słownictwa więc starałam się nie uciekać, za to pewnie dlatego ze słownictwem nie było takiego problemu". [JK]

Dane pochodzące z wypowiedzi studentów wskazują na dość wysoką świadomość współzależności kompetencji językowej i dyskursywnej występującą w obu zadaniach. Studenci przyznają, że zależność ta jest zautomatyzowana w języku polskim, natomiast w języku francuskim dominuje dbałość o dopasowanie środków językowych, które w fazie produkcji (odtwarzania opowiadania) dobierane są za pośrednictwem języka polskiego. W sposób naturalny spowalnia to proces rozumienia tekstu, a czasami wręcz uniemożliwia dokonanie interpretacji i skupienie się na wydarzeniach uznanych przez odbiorców za mniej istotne. Studenci przyznają, że interpretacja opowiadania w języku francuskim zasadzała się bardziej na ich doświadczeniu i wynikających z niego przypuszczeniach niż na elementach tekstu wyłonionych w trakcie odsłuchu. Tym samym znajomość gatunku tekstu, umiejętność antycypowania treści składające się na doświadczenie dyskursywne mogły pełnić funkcje kompensujące 
Przeformułowanie w przyswajaniu i uczeniu się języków: specyfika i funkcje...

niektóre deficyty językowe w sytuacji odbioru, a w sytuacji produkcji (odtwarzania) pozostawiać potrzebę uzupełniania tekstu o elementy uspójniające przedstawione wydarzenia.

\section{Podsumowanie i wnioski}

Zestawienie dwóch sytuacji dydaktycznych w przedstawionym badaniu własnym (odtwarzania tekstu w języku ojczystym i w języku obcym) pozwala prześledzić udział kompetencji dyskursywnej w zapamiętywaniu i przetwarzaniu przykładowej realizacji gatunku, opowiadania. Mimo ograniczonych rozmiarów pozwala ono dostrzec priorytety uczniów w sytuacji niedoboru uwagi oraz wynikających z tej sytuacji konsekwencji dla rodzaju pozyskiwanych zasobów.

Przeprowadzone badanie pozwala stwierdzić, że zarówno w języku ojczystym, jak i w języku obcym studenci wkładają wiele wysiłku w budowanie spójności tekstowej, choć ze zrozumiałych względów środki wykorzystane w tym celu są zdecydowanie uboższe $w$ drugiej sytuacji (zob. Karpińska-Szaj i Wojciechowska, 2015). Skupienie uwagi na istotnych cechach tekstu, przede wszystkim na zapamiętaniu i odtworzeniu głównych wydarzeń świadczy naszym zdaniem o mniej lub bardziej uświadomionym działaniu ucznia nakierowanym na uchwycenie najistotniejszych elementów opowiadania, stanowiących o jego istocie i logice wewnętrznej. Odbywa się to często kosztem elementów należących do drugiego planu opowiadania związanych z motywacjami i emocjami, jakie towarzyszą bohaterom oraz z pominięciem warstwy retorycznej zawierającej oceny i sugestie skierowane do odbiorcy opowiadania. Szczególnie pierwsze z wymienionych tutaj działań dyskursywnych częściowo uzupełniane było przez uczniów w oparciu o kompetencję dyskursywną w języku ojczystym i w tym znaczeniu można uznać, że ma ono charakter kompensacyjny (zob. Karpińska-Szaj i Paprocka-Piotrowska, 2014). Przejawia się ono przede wszystkim w dodawaniu elementów typowych dla treści drugoplanowych, nieobecnych w tekście wyjściowym, a niezwykle istotnych dla interpretacji opowiadania i jego atrakcyjności dla słuchacza.

Wydaje się jednak, że strategiczne wybory ucznia, tj. skupienie uwagi na głównych wydarzeniach z pominięciem motywacji i uczuć bohaterów oraz kompensowanie tych ostatnich w oparciu o własną wiedzę - ma dość ograniczoną wartość uczeniową. Uświadomienie z jednej strony struktury gatunkowej opowiadania oraz jego retorycznego charakteru, ukierunkowanego na emocje i oczekiwania odbiorcy, sygnalizującego implicytnie wartości, wprowadzającego elementy zaskoczenia czy cudowności, a z drugiej strony refleksja nad środkami językowym, które uczestniczą w konstruowaniu tych funkcji mogłoby 
pomóc w bardziej zorganizowanym podejściu do obserwowania realizacji gatunków w języku obcym. Ze względu na ograniczone zasoby uwagi na poziomie A2, gdy spora część procesów niższego rzędu nie jest jeszcze zautomatyzowana, należałoby zaproponować takie zadania dydaktyczne, które uwzględniałyby aktualny poziom kompetencji komunikacyjnej uczniów w języku obcym oraz specyfiki tekstu wyjściowego. Na tej podstawie oraz na podstawie obserwacji własnych działań w obu typach sytuacji dydaktycznych można by wypracować wraz z uczniami zadania mające na celu rozwijanie wybranych strategii (np. zapamiętać, jakie struktury językowe służą łączeniu elementów tła z głównym wydarzeniami, albo jak wydarzenia główne są rozpisane na bardziej szczegółowe czynności) $i$ ich stopniowe uzupełnianie w ramach hierarchicznie zbudowanej struktury. Można się spodziewać, że stworzyłoby to możliwość przeznaczenia większej części zasobów uwagi na jednostki niższego rzędu bez oddzielania ich od normy dyskursywnej. Systematyczna praca w tym kierunku stwarza możliwość wypracowania przez uczniów samodzielnych strategii zarządzania własnym zasobami poznawczymi i dyskursywnymi w kontakcie z dokumentami autentycznymi. Taka wspólna praca z uczniami umożliwia rozwijanie samodzielności ucznia w zakresie korzystania z danych językowych i dyskursywnych w zależności od własnych potrzeb i ambicji. Ma ona także wartość diagnostyczną dla nauczyciela i pozwala w bardziej uporządkowany sposób obserwować i wspomagać postępy ucznia.

\section{BIBLIOGRAFIA}

Bartning, I. i Kirchmeyer, N. 2003. "Le développement de la compétence textuelle à travers les stades acquisitionnels en français L2". AILE 19: 9-39.

Bronckart, J.-P. 1996. "L'acquisition des discours. Le point de vue de l'interactionnisme socio-discursif". Le Français dans le Monde. Le discours: enjeux et perspectives. $\mathrm{N}^{\circ}$ spécial: $55-64$.

Bronckart, J.-P. 2008. "Du texte à la langue, et retour: notes pour une "reconfiguration" de la didactique du français". Pratiques 137-138: 97-116.

Canut, E. i Vertalier, M. 2010. “Etudier la complexité syntaxique chez l'enfant de moins de six ans dans une perspective interactionnelle: choix d'une méthodologie qualitative" (w) Interactions verbales et acquisition du langage (red. Bernicot, J., Venziano, E. i Musiol, M.). Paryż: L’Harmattan: 239-260.

Europejski System Opisu Kształcenia Językowego: Uczenie się, Nauczanie, Ocenianie. 2003. Warszawa: Wydawnictwa CODN.

Karpińska-Szaj, K. 2015. "Przygotowanie do pracy z uczniami o specjalnych potrzebach edukacyjnych: językowe narzędzia diagnostyczne w praktyce nauczycielskiej". Neofilolog 45/2: 187-202. 
Karpińska-Szaj K. i Paprocka-Piotrowska, U. 2014. "La reformulation en tant que stratégie d'apprentissage d'une LE: vers son exploitation dans des situations nonordinaires". Roczniki Humanistyczne LXII/10 Glottodydaktyka: 55-82.

Karpińska-Szaj, K. i Wojciechowska, B. 2015. "La performance morphosyntaxique dans les tâches de reformulation écrite. Cas d'étudiants débutants de FLE". Neofilo$\log$ 44/1: 73-90.

Martinot, C. 2012. "De la reformulation en langue naturelle, vers son exploitation pédagogique en langue étrangère: pour une optimisation des stratégies d'apprentissage" (w) Autour de la compétence d'apprentissage de langues: gestion des ressources métacognitives et cognitives. (red. Karpińska-Szaj, K. i Zając, J.). Synergies-Pologne 9: 63-76.

Préneron, C. i Martinot, C. (red.). 2013. “Récits d'enfants et d'adolescents : développement typiques, atypiques, dysfonctionnements". Approche neuropsychologique des apprentissages chez l'enfant N¹24/ volume 25/ tome III: 233-348.

Py, B. 1996. "Les données et leur rôle dans l'acquisition d'une langue non maternelle" (w) La construction interactive des discours de la classe de langue. Les carnets du Cediscor. Paris: Presses de la Sorbonne Nouvelle: 95-110.

Véronique, D. 2005. "Les interrelations entre la recherche sur l'acquisition du français langue étrangère et la didactique du français langue étrangère. Quelques pistes de travail". AILE 23: 9-41. 


\section{Załącznik}

\section{A. Tom et Julie - wersja w języku francuskim z podziałem na sekwencje}

1) Ce matin-là, la maîtresse est arrivée dans la cour de l'école plus tard que d'habitude. Elle tenait par la main une petite fille que personne n'avait encore jamais vue.

2) Arrivée en classe, la maîtresse a dit : « Les enfants, je vous présente votre nouvelle camarade, elle s'appelle Julie. Tom, la place est libre à côté de toi. Julie sera ta voisine, sois bien gentil avec elle ! »

3) Tom était fou de joie à l'idée d'avoir peut être une nouvelle amie. Le soir, chez lui, il a fabriqué une petite boîte ronde, rouge et dorée, pour Julie.

4) Le lendemain matin, dans la cour de l'école, Tom guettait l'arrivée de sa nouvelle petite voisine. Dès qu'il l'a aperçue, il s'est dirigé vers la fillette et lui a tendu la boîte qu'il avait fabriquée pour elle, la veille.

5) Julie aimait tellement cette boîte qu'elle la prenait toujours avec elle. Quand la maîtresse disait : " Sortez vos affaires ! ॥, Julie posait délicatement la boîte entre Tom et elle, sur leur table de travail.

6) Un jour, Julie chuchota à Tom : « Ouvre la boîte ! " Tom souleva le couvercle et découvrit un morceau de papier sur lequel Julie avait écrit: « Je t'attends ce soir à 8 h, sous le gros arbre, à l'entrée de la forêt ".

7) Tom avait un peu peur parce qu'il lui était interdit d'aller dans la forêt, surtout la nuit.

8) Mais à $8 \mathrm{~h}$ du soir, il était tout de même au rendez-vous, Julie l'attendait déjà.

9) Sans dire un mot, la petite fille prit la main de Tom et frappa 3 fois sur le tronc du gros arbre.

10) Au bout de quelques minutes, les enfants entendirent un grincement. L'arbre était en train de tourner sur lui-même.

11) Tout à coup, le tronc s'ouvrit et les enfants furent éblouis par la lumière qui inondait l'intérieur de l'arbre. Ils firent quelques pas et l'arbre se referma derrière eux.

12) Tom et Julie se trouvaient dans un jardin merveilleux où les fleurs semblaient se parler en chantant. Alors Julie dit à Tom : « Viens, traversons le jardin, il y a une grande fête pour toi, ce soir. Jusqu'à minuit, tu as le droit de demander à notre Roi tout ce que tu veux ».

13) Tom a répondu : " Je veux apprendre à parler avec les oiseaux qui savent tout ce qui se passe dans le ciel, avec les poissons qui savent tout ce qui se passe dans l'eau et avec les fourmis qui savent tout ce qui se passe sur la terre ".

14) Et depuis ce jour, Tom est devenu un enfant extrêmement savant.

\section{B. Tomek i Julka - wersja w języku polskim z podziałem na sekwencje}

1) Tego ranka Pani weszła na szkolne podwórko później niż zwykle. Trzymała za rękę dziewczynkę, której nikt dotąd nie widział.

2) Po wejściu do sali Pani powiedziała "Dzieci, przedstawiam wam nową koleżankę, ma na imię Julka. Tomku, miejsce obok Ciebie jest wolne, Julka będzie siedzieć obok Ciebie, bądź dla niej miły!". 
Przeformułowanie w przyswajaniu i uczeniu się języków: specyfika i funkcje...

3) Tomek bardzo się cieszył, że być może będzie miał nową dobrą koleżankę. Wieczorem w domu zrobił dla Julki okrągłe złoto-czerwone pudełeczko.

4) Nazajutrz rankiem, na szkolnym podwórku Tomek niecierpliwie wyglądał przybycia swojej nowej sąsiadki. Gdy tylko ją spostrzegł, podbiegł do niej i wręczył jej pudełko, które zrobił dla niej poprzedniego wieczoru.

5) Julce pudełeczko tak się spodobało, że nosiła je zawsze przy sobie. A kiedy pani mówiła: "Wyjmijcie swoje rzeczy”, Julka delikatnie kładła pudełeczko na ławce, pomiędzy nią i Tomkiem.

6) Pewnego dnia Julka szepnęła do Tomka: “Otwórz pudełko!”. Tomek podniósł pokrywkę i zobaczył karteczkę, na której Julka napisała: "Czekam na Ciebie dziś wieczorem o 8.00, pod wielkim drzewem przy wejściu do lasu".

7) Tomek trochę się bał bo nie wolno mu było chodzić do lasu a już zwłaszcza nocą.

8) Jednak o 8.00 stawił się na spotkanie. Julka już na niego czekała.

9) Bez słowa dziewczynka wzięła Tomka za rękę i trzy razy zastukała w pień wielkiego drzewa.

10) Po kilku minutach dzieci usłyszały jakieś skrzypienie. To drzewo obracało się wokół siebie.

11) Nagle pień drzewa otworzył się a dzieci olśniło światło wydobywające się z jego wnętrza. Gdy zrobili kilka kroków, drzewo zamknęło się za nimi.

12) Tomek i Julka znaleźli się w cudownym ogrodzie, gdzie wydawało się, że kwiaty rozmawiają ze sobą śpiewając. Wtedy Julka powiedziała do Tomka: "Chodź, przejdźmy przez ogród, dziś wieczór jest przyjęcie na twoją cześć. Aż do północy możesz prosić naszego Króla o co tylko chcesz".

13) Tomek odpowiedział "Chcę nauczyć się rozmawiać z ptakami, które wiedzą o wszystkim co się dzieje w niebie, z rybami, które wiedzą o wszystkim co się dzieje w wodzie i z mrówkami, które wiedzą o wszystkim co się dzieje na ziemi.

14) I od tego dnia, Tomek stał się bardzo mądrym dzieckiem. 